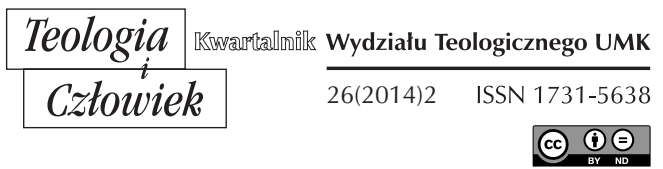

MIECZYSŁAW C. PACZKOWSKI OFM*

\title{
AMALEK AND THE AMALEKITES IN THE ANCIENT CHRISTIAN LITERATURE
}

DOI: http://dx.doi.org/10.12775/TiCz.2014.021

The purpose of this study is to investigate the importance of Biblical figure of Amalek and Amalekites in the Patristic tradition, with a view to explaining the absence of the name in the New Testament, but with the large reflex ions in the rabbinical sources.

\section{THE BACKGROUND OF THE PATRISTIC TRADITION}

The name Amalek ${ }^{1}$ occurs in the Scriptures in Genesis, Exodus, Numbers, Deuteronomy, Judges, 1 and 2 Samuel, 1 Chronicles and in Psalm 83. The kind of information given is sometimes genealogical ${ }^{2}$,

* Dr hab. Mieczysław Paczkowski (Celestyn) - franciszkanin (OFM) jest pracownikiem naukowym (teologia Kościołów Wschodnich, patrologia, ekumenizm, historia egzegezy) na Wydziale Teologicznym UMK w Toruniu.

${ }^{1}$ Translated as "Amalek" or as "Amalekites" or as "an Amalekite". See M. North, Amalekiter, in: Die Religion in Geschichte und Gegenwart, Tubinga 1956³ , kol. 302; F. Schmidtke, Amalekiter, in: Lexikon für Theologie und Kirche, vol. 1, Fryburg 1957, kol. 414-415.

${ }^{2}$ E.g. Gen 36:12.16 where Amalek is descended from Esau. See Ph. Stern (transl. jm), Amalek, in: B.M. Metzger-M.D. Coogan (ed.), Stownik wiedzy biblijnej, Warszawa 1996, p. 11. 
sometimes geographical ${ }^{3}$, while often the Amalekites are involved in accounts of conflicts ${ }^{4}$. There the Amalekites sometimes occur listed together with others ${ }^{5}$ and sometimes on their own ${ }^{6}$. Occasionally an individual Amalekite is mentioned ${ }^{7}$. Among Balaam's oracles there is one pronounced against Amalek (see Num 24:20) ${ }^{8}$.

For the biblical background two texts receive particular value: Exod 17:8-16 and Deut 25:17-19 ${ }^{10}$. The rabbinic literature treated systematically this figure. Two rabbinical texts ${ }^{11}$ collect together a wide variety of

${ }^{3}$ E.g. Num 13:29 where the men report to the Israelites, after having spied out the Land, that the Amalekites occupy the Negev area. See the opinion of R. Cohen according to S. Gądecki, Archeologia biblijna, vol. 1, Gniezno 1994, p. 292.

${ }^{4}$ See J. Bright, A History of Israel, London 1972, p. 122-123.

${ }^{5}$ E.g. Jud 6:3 where they appear together with the Midianites and the Sons of the East.

${ }^{6}$ E.g. Exod 17:8-16.

${ }^{7}$ See 2 Sam 1:8.13 which is one of the traditions of the death of Saul, the Lord's anointed, here killed by an Amalekite, whom David subsequently has killed.

${ }^{8}$ NJB translates, "Amalek, the earliest of nations! But his posterity will perish forever", although the Hebrew text is not clear in its precise meaning. In an earlier oracle in favour of Israel, Num 24:7 says, according to NJB, "His King is greater than Agag", where Agag would be the Amalekite king spared by Saul but killed by Samuel in 1 Sam 15:32-33, but here again the Hebrew text is not certain . It is a curse and contrasts with the blessing pronounced upon the Kenites.

${ }_{9}$ In Exod 17:8-16, the Targum says where Amalek came from, and what a great distance he travelled, and says that he attacked Israel because of the enmity which existed between Esau and Jacob. The Israelites killed were from the tribe of Dan, thrown out from under the protection of the cloud because they were practisers of idolatry. Moses on the hilltop had his hands held up in prayer. Amalek had "cut off the heads of the mighty men of his [Joshua's] people".

${ }_{10}$ Deut 25:17-19 also specifies the Dannites as those who are killed by Amalek, again for their idolatry. Here, however the Aramaic does not say that Amalek "cut off the heads of the mighty men" as in Exod 17:13, but rather "cut off their male parts" and then "threw them in the air". the final note, to "remember", includes reference to the days of the King Messiah.

${ }^{11}$ This is Pesiqta deRab Kahana (Pisqa 3) and tractatus Amalek I-II w: Mekilta of rabbi Iszael. Ed. and transl. J.Z. Lauterbach, Mekilta de-Rabbi Ishmael (Jewish Publication Society), Filadelfia 1933; H.S. Horovitz-I.A. Rubin (ed.), Mechilta d'rabbi Ismael, Jerusalem 1970; J. Neusner, Pesiqta deRev Kahana (Brown Judaic Studies 122), Atlanta 1987; B Mandelbaum (ed.), Pesikta de Rav Kahana according to an Oxford Manuscript (Jewish Theological Seminary of America), vol. 1-2, New York 1987. The location of texts in rabbinic literature has been facilitated by the introduction of computerised concordances and digital versions. 
comments on Deut 25:17-1912 and Exod 17:8-16 respectively, and in so doing bring in almost all the other references to Amalek in Scripture, as well as raising and attempting to answer questions ${ }^{13}$.

In the past a lot has been done to underline the importance of rabbinic literature as a source to scrutinize the background of the Christian Biblical interpretation. It is necessary consider rabbinic traditions as late and polemical. The Midrash ${ }^{14}$ represents, on the one hand, evidence of how commonly the name Amalek occurs on the lips of the rabbis, and, on the other, evidence that Amalek is "the enemy" of Israel and of God. Even though the Amalekites as a people no longer exist, an enemy is ever present or threatening to be present. This conviction testifies his appearance in the liturgy of the synagogue. Some of the traditions about Amalek are to be found repeatedly throughout the various midrashic works. Further study could be done on the history of these traditions by comparing parallels. The difficulty of dating them could then be followed up with a comparison with parallels in the Targums ${ }^{15}$ and in Hellenistic, Qumranic, Patristic and Pseudepigraphic literature ${ }^{16}$. The identification of Amalek with evil spirits who assail the Christian presents grounds for comparing and contrasting the overall view of the Midrash and that of the most important early - Christian scholars. Comparison with Justin's Dialogue or Origen offers the significant examples of contact between the Church Fathers and Rabbinic literature ${ }^{17}$. Origen's homilies provide evidence that Amalek is not an unknown foe to the Christian. In

${ }_{12}$ Deut 25:17-19 seems to present even fewer difficulties. The Latin and Greek both attribute to Amalek the words that "and [was] not fearing God". All agree on "God" and not "the Lord" - as in Exod 17:9b where all three have "God" (there is disagreement only in Exod 17:16 where the Latin has "bellum Dei" against the Hebrew and Greek).

13 The location of texts in the early Patristic authors was made using the index of citations and Biblical allusions called Biblia Patristica.

${ }^{14}$ See Midrash, in: Encyclopaedia Judaica, p. 1507-1523; F. Manns, Le Midrash Approache et Commentaire de l'Écriture, Jerusalem 1990.

15 The Targum shows itself not only to be a paraphrase, but also a place where comments are collected. The text is noticeably longer, but the additional material is not simply a wordier way of saying the same thing.

${ }^{16}$ The critical apparata we can find in following editions: Hebrew (MT), Latin (Vulgate), Aramaic (Targum Pseudo-Jonathan according to the manuscript Add. 27031 in the British Museum) and Greek (LXX).

${ }_{17}$ F. Bergamelli, Il metodo nello studio dei Padri: Problemi, orientamenti e prospettive, in: E. Dal Covolo, A.M. Triacca (ed.), Lo studio dei Padri della Chiesta oggi (Biblioteca di Scienze Religiose 96), Roma 1991, p. 19-43. 
early Patristic tradition, this Alexandrian author stands out as the only commentator who treats Amalek sufficiently to make him worth including here systematically. His Homilies in Exodus and Homilies in Numbers ${ }^{18}$ must be treated in detail. The first work covers Exod 17:8-16 and the latter the Balaam oracles ${ }^{19}$ and texts from Gen, Deut, and 1 and 2 Sam. Justin Martyr's and Irenaeus' comments on Amalek exist too.

Let us see the notes on Amalekites in the Josephus ${ }^{20}$ and Philo of Alexandria ${ }^{21}$. The first author, the well-known historian of the first century, is usually studied in this context in order to find parallels to traditions found in later literature, and so to date them and provide further evidence for the study of the development of traditions. The Christians educated in the Hellenistic culture liked to read the authors, who adapted the literal form according what the people liked. In this way the writer was giving the possibility to the people to discover the difficult passages of the Old Testament. The victory on the Amalekites is for the author the opportunity to exalt the Israelites. Even though there are not details concerning the battle with Amalekites, a passage of the Jewish Antiquities"2 explains: "The Hebrews conquered the Amalekites by main force ${ }^{23}$; and indeed they had all perished, unless the approach of the night had obliged the Hebrews to desist from killing any more. So our forefathers obtained a most signal and most seasonable victory"24.

${ }^{18}$ See Homilia in Exodum XI,1-4 and Homiliae in Numeros XVIII, 4-XIX,2. For the text see W.A. Baehrens, Origenes Werke 6: Homilien zum Hexateuch in Rufins Übersetzung/1: Die Homilien zu Genesis, Exodus und Leviticus (Die griechischen christlichen Schriftsteller 29), Leipzig 1920; Id., Origenes Werke 7: Homilien zum Hexateuch in Rufins Übersetzung/2: Die Homilien zu Numeri, Josua und Judices (Die griechischen christlichen Schriftsteller 30), Leipzig 1921.

19 Prophecy of Balaam was a frequent motif in early Christian art.

${ }^{20}$ See J. Maier, Amalek in the Writings of Josephus, in: F. Parente, J. Sievers (ed.), Josephus and the History of the Greco-Roman Period: Essays in Memory of Morton Smith, Leiden 1994, p. 115-120; Ch. Begg, Israel's Battle with Amalek according to Josephus, Jewish Studies Quarterly 4 (1997), p. 203-204.

${ }^{21}$ See W.J. Robbins, A Study in Jewish and Hellenistic Legend with Special Reference to Philo's Life of Moses (doctoral dissertation on the Brown University), Providence - Rhodes Island 1947, p. 92-95.

${ }^{22}$ Josephus Flavius, Jewish Antiquities (The Loeb Clasical Library), 10 vols, London 1981. The index volume is No. 456.

23 "They fought against the Hebrews, and this when they were in the wilderness"; Antiquitates Judaicae II,5.

${ }^{24}$ Antiquitates Judaicae II,4. 
Flavius in the certain point tries hard to justify the cruelty of the biblical times. He writes that Saul ${ }^{25}$ had to put to death all the Amalekites without exception, because "he [Saul] betook himself to slay the women and the children, and thought he did not act therein either barbarously or inhumanly; first, because they were enemies whom he thus treated, and, in the next place, because it was done by the command of God, whom it was dangerous not to obey" ${ }^{\prime \prime 26}$. There is no mention about nationalistic references to the "enemies of Israel". It was that because Josephus presented different aspects of this moments than the rabbis. For him was enough to present the heroic deed of his ancestors, meanwhile the rabbis fought against the Christianity to preserve the pure tradition of the Judaism.

The famous Philo of Alexandria appears noteworthy example of the large interchange and interaction of ideas in Alexandria of Egypt. His interest is principally a philosophical system applied to the Scriptures ${ }^{27}$. He was able to find this sense in Biblical text and considered it a "profound" one. Philo does not indicate Amalek to be evil spirits, but rather the personification of "passion", albeit hostile to the good of the soul28.

"According to the superiority of the mind when it applies itself to incorporeal objects, which are perceptible only to the intellect, passion is put to flight. And, on the other hand, when this latter gains a shameful victory, the mind yields, being hindered from giving its attention to itself and to all its actions. At all events, he says in another place, "When Moses lifted up his hands Israel prevailed, and when he let them down Amalek prevailed»(Ex 17:11). And this statement implies, that when the mind raises itself up from mortal affairs and is elevated on high, it is very vigorous because it «beholds God»; and the mind here means «Israel $»^{29}$. But when it relaxes its vigor and becomes powerless, then

${ }^{25}$ See L.H. Feldman, Josephus' Portrait of Saul, Hebrew Union College Annual 53 (1982), p. 96.

${ }^{26}$ Antiquitates Judaicae VII, 2. See Ch. Begg, Saul's War with Amalek according to Josephus, Laurentianum 37 (1996), p. 396-397, notes 73-74, 79.

27 See S. Matuszewski, Filozofia Filona z Aleksandrii $i$ jej wptyw na wczesne chrześcijaństwo, Warszawa 1962; S. Sandmel, Philo Judaeus. An Introduction to the Man, His Writings, and His Significance, in: Aufstieg und Niedergang der römischen Welt, II: Principat, Berlin 1984, p. 731-759; R. Williamson, Jews in the Hellenistic World, II: Philo, Cambridge 1989.

${ }^{28}$ E.g. Philo, Leges allegoriarum III 187 (in the Loeb Classical Library this is found in No. 226).

${ }^{29}$ It was very popular etymology. See Excerpta ex Theodoto 56,5; Augustine of Hippo, De civitate Dei XVII,13; Enarrationes in Ps. 124,10. 
immediately the passions will prevail, that is to say, Amalek; which name, being interpreted, means, and the people licking. For he does, of a verity, devour the whole soul, and licks it up, leaving no seed behind, nor anything which can excite virtue; in reference to which it is said: "Amalek is the beginning of Nations» (Num 24:20) because passion governs, and is the absolute lord of nations, all mingled and confused and jumbled in disorder, without any settled plan; and, through passion, all the war of the soul is fanned and kept alive. For God makes a promise to the same minds to which he grants peace, that he will efface the memorial of Amalek from all the lands beneath the heaven" ${ }^{\prime 30}$. The moral allegory was used in this case in order to emphasized the antagonism between passion and mind.

Exod 17:8-16 receives a fuller commentary in The life of Moses ${ }^{31}$. The Jewish philosopher indentifies the Amalekites with the Phoenicians! The hands of Moses liked the balances in a scale. His exegesis of the holding up of Moses' arms is particularly interesting.

"And just as the two armies were about to engage in battle, a most marvelous miracle took place with respect to his hands; for they became by turns lighter and heavier... God showing thus by a figure that the earth and all the extremities of it were the appropriate inheritance of the one party, and the most sacred air the inheritance of the other. And as the heaven is in every respect supreme to and superior over the earth, so also shall the nation which has heaven for its inheritance be superior to their enemies" ${ }^{\prime 32}$.

According with the Philonic interpretation, one raises thoughts and actions away from the earth and up toward heavenly and immaterial realities. Philo also focused: "They became quite devoid of weight, using their fingers as if they were wings, and so they were raised to a lofty height, like winged birds who traverse the heaven, and they continued at this height until the Hebrews had gained an unquestionable victory, their enemies being slain to a man from the youth upward, and suffering with justice what they had endeavored to inflict on others, contrary to what was befitting" ${ }^{\prime \prime 3}$.

\footnotetext{
${ }^{30}$ Leges allegoriarum III 66,186-187.

${ }^{31}$ See De vita Moisis (see Loeb No. 289).

${ }^{32}$ De vita Moisis I 39,217.

${ }^{33}$ Ibidem 218.
} 
The Jew's philosopher makes the final conclusion in this way: "Then Moses erected an $\operatorname{altar}^{34}$, which from the circumstances that had taken place he named the refuge of $\operatorname{God}^{35}$, on which he offered sacrifices in honor of his victory, and poured forth prayers of gratitude to God"36. Philo says in Allegorical Interpretation that Amalek not only licks up, but eats up the soul before licking it out ${ }^{37}$.

The Alexandrian Jew applies this idea only in the certain aspects. He is convinced that Amalek presents also the forces which works against the human being. This is different view of the idea of an antagonism between an immanent God and sin is a feature of the Rabbinic conception ${ }^{38}$. „Therefore the wise Abraham is said to have returned again from the slaughter of Chedorlaomer, and of the kings who were with Him (Gen 14:17) ${ }^{39}$. And on the other hand, Amalek is said to have cut to pieces the rear of the company of the mediator of virtue (De 25:18) in strict accordance with the truth of nature; for what is contrary to one is also hostile to the other, and such things are always meditating the destruction of one another ${ }^{\prime \prime 4}$.

\section{EARLY CHRISTIAN INTERPRETATION OF AMALEK AND THE AMALEKITES}

The translation of Septuagint opened the way to the Christological interpretation of Exod 17:16 ${ }^{41}$. Christian scholars emphasized on the powerful force of the cross, as one can read in the Sibylline Oracles: „Immortal King, who suffered for our sake; him Moses typified when

${ }^{34}$ See Alleg. in Genesim II 2,187.

35 Also "taking refuge in God".

36 De vita Moisis I 39,219.

37 See Leges allegoriarum III,186-187.

${ }^{38}$ E.g. Exodus Rabba 28 and 29.

${ }^{39}$ Genesis Rabba 42,7 comments on the problem of Gen 14:7 by quoting Isaiah 46:10 ("I recount from the very beginning what will happen later"). God knows the future before it happens, and even predicts it: before Amalek is born (Gen 36:12.16), his lands have been overrun in anticipation (Gen 14:7)! i.e. - Gen 42:7 refers to an area of land as the land of the Amalekites before it actually becomes such.

40 De ebrietate VII,24.

41 The negative rabbinic tradition about the Septuagint presents an anti-Christian counternarrative. Nevertheless, by continuing to couch the debate over the legitimacy of the Septuagint in terms of the legend, however altered, the rabbis engaged Christians in a common forum of debate. See Megilla 9a. 
he stretched out holy arms, conquering Amalek by faith, that the people might know him to be elect and honorable before his Father God"42. The Christian author probably worked up Jewish materials ${ }^{43}$ in composing his poems and emulated the ancient Sibylline oracles ${ }^{4}$.

The "topos" of Amalek and the Amalekites does not occur in the Apostolic Fathers ${ }^{45}$, but is evident to other authors of early Christian era. Let us examine St. Justin Martyr (2nd century). He began the practice of using Old Testament historic passages describing the Christian Creed. He appeals to historical events for validation of Christian interpretations of the fulfillment of prophecies. The Apologist also accentuates the contrast between the faith of the gentiles and Jewish incredulity. This point of view did not please to the Jewish scholars ${ }^{46}$. The Dialogue with Trypho points out that Justin apart from his profound knowledge of the Bible, he knew very well the Jewish ${ }^{47}$. In some parts of his Dialogue the apologist presents the pre-announcement about the crucifixion of Christ in the Old Testament ${ }^{48}$. In Exod 17: 8-16 he notes two symbols of the passion of Christ. The first is

${ }^{42}$ Oracula Sybillina VIII, 330-334.

43 "Then shall perish the seed of Canaan, and a remnant shall not be unto Amalek, and all the Cappadocians shall perish, and all the Hittites shall be utterly destroyed"; Testamentum Simeonis 4.

${ }^{44}$ See A. Hamman, Oracoli sibillini II, in: A. Di Berardino (ed.), Nuovo dizionario patristico e di antichitŕ cristiane, vol. 2, Genova-Milan 2007, c. 3638.

${ }^{45}$ According to the opinion of Simonetti, it may be affirmed the first Christian generations developed only "embryonic approaches" of biblical exegesis. See Id., Per tipica ad vera. Note sull'esegesi di Ireneo, Vetera Christianorum 18 (1981), p. 357.

${ }^{46}$ Por. M. Hirshman, Polemic Literary Units in the classical Midrashim and Justin Martyr's Dialogue with Thrypho, Jewish Quarterly Review 83 (1993), p. 369-384.

${ }^{47}$ For the examples see L. Misiarczyk, Il midrash nel Dialogo con Trifone di Giustino martire, Płock 1999.

${ }^{48}$ See Dial. cum Trypho 90-91; 111-112; 131. The anonymous Epistle, attributed to St. Barnabas, explains: "Here again you have an intimation concerning the cross, and Him who should be crucified. Yet again He speaks of this in Moses, when Israel was attacked by strangers. And that He might remind them, when assailed, that it was on account of their sins they were delivered to death, the Spirit speaks to the heart of Moses, that he should make a figure of the cross, and of Him about to suffer thereon; for unless they put their trust in Him, they shall be overcome for ever. Moses therefore placed one weapon above another in the midst of the hill, and standing upon it, so as to be higher than all the people, he stretched forth his hands, and thus again Israel acquired the mastery. But when again he let down his hands, they were again destroyed. For what reason? That they might know that they could not be saved unless they put their trust in Him". Ep. Barnabae XII,2; see T.W. Manson, The Argument from Prophecy, Journal of Theological Studies 46 (1945), p. 135. 
Moses who prayed like Jesus with the opened arms on the cross ${ }^{49}$. According to Justin the final victory on the Amalekites took place on the Christ's cross. In fact only in this moment the Evil was completely destroyed ${ }^{50}$.

"A sign of Him who was to be crucified was given to you..., both in the case of the serpents that bit you... and in the case of Moses, by the sign of his outstretched arms, and of Hoshea, by his being named Jesus when they were waging war against Amalek, which fact God commanded to be recorded, having admonished you not to forget the name of Jesus, who was to erase the memory of Amalek from the face of the earth. However, it is obvious that the memory of Amalek still remains after the time of the son of Nave. God makes it clear that by the Crucified Jesus (of whom even those signs were predictions of what would happen to Him) the demons were to be destroyed, and to shudder at His name; and that all the authorities and kingdoms were to tremble before Him; and that out of every nationality those who believe in Him would be shown to be pious and peaceful" ${ }^{\prime \prime 2}$.

The presence of Christ in the world, in the Church and also in the every believers, is the key which permit to open the mystery of the Bible. For Justin the passage from the darkness to the light of the true it is possible exclusively to the person who accepts the true of the salvation in the Christ. Joshua ${ }^{52}$ is compared to Christ: "This name then being given him when he sent him to spy out the land, he said: «Take a book into thy hands, and write what the Lord declares, that the Son of God will in the last days cut off from the roots all the house of Amalek». Behold again: Jesus who was manifested, both by type and in the flesh, is not the Son of man, but the Son of God"53.

49 See Tertullian, Adversus Marcionem III,19. Also M. Simonetti, Lettera e/o allegoria. Un contributo alla storia dell'esegesi patristica (Studia Ephemeridis "Augustinianum” 23), Rome 1985, p. 316, note 298.

${ }^{50}$ See Dial. cum Trypho 131.

${ }^{51}$ Dial. cum Trypho 131.

52 "God took of the spirit which was in Moses and put it on Joshua... For the Lord said He would wage war against Amalek with concealed hand; and you will not deny that Amalek fell. But if it is said that only in the glorious advent of Christ war will be waged with Amalek, how great will the fulfillment of Scripture be which says, 'God will wage war against Amalek with concealed hand!' You can perceive that the concealed power of God was in Christ the crucified, before whom demons, and all the principalities and powers of the earth, tremble"; Dial. cum Trypho 49.

${ }^{53}$ Dial. cum Trypho 12. 
In the Dialogue with Trypho ${ }^{54}$ Justin is eager to demonstrate how the crucifixion of Jesus is already present in the Scriptures in the form of "types and parables". In Exod. 17:8-13, Justin sees two representations of the cross: the lifting up of the hands of Moses in imitation of the cross, and the name of Jesus ${ }^{55}$ at the head of the fighting, representing the sign of the cross. The apologist makes explicit that the defeat of Amalek is fulfilled in Jesus crucified, which is the defeat of the demons.

"When the people... waged war with Amalek, and the son of Nave (Nun) by name Jesus (Joshua), led the fight, Moses himself prayed to God, stretching out both hands, and Hur with Aaron supported them during the whole day, so that they might not hang down when he got wearied. For if he gave up any part of this sign, which was an imitation of the cross, the people were beaten, as is recorded in the writings of Moses; but if he remained in this form, Amalek was proportionally defeated, and he who prevailed by the cross... For some out of all the nations, through the power of this mystery, having been so pushed, that is, pricked in their hearts, have turned from vain idols and demons to serve God. But the same figure is revealed for the destruction and condemnation of the unbelievers; even as Amalek was defeated and Israel victorious when the people came out of Egypt, by means of the type of the stretching out of Moses' hands, and the name of Jesus (Joshua), by which the son of Nave (Nun) was called"56.

Irenaeus of Lyon mentions Amalek three times in his work Adversus Haereses (books III and IV) ${ }^{57}$. The Lyon's bishop makes an analysis of the different adorations of Jesus as a child. At the very beginning, he deals with the visit of Mages who came from the East, and then he makes the reference to Is $8: 4^{58}$. "«He shall receive the power of Damascus, and the spoils of Samaria, against the king of the Assyrians» (Is 8:4); declaring, in a mysterious manner indeed, but emphatically, that the Lord did fight with a hidden hand against Amalek (see Exod 17:16) ${ }^{59}$. For this cause,

${ }^{54}$ See $90-91 ; 111-112 ; 131$.

${ }^{55}$ Even in Hebrew Joshua is the same name as Jesus in another form. Justin knew also the Hebrew text of the Scriptures and was willing to quote them so as not to compromise his argument, as illustrated in 131,1.

${ }^{56}$ Dial. cum Trypho 90-91.

${ }^{57}$ It is available with text and translation in Sources Chrétiennes. See Irénée de Lyon, Contre les Hérésies (Sources Chrétiennes 211), Paris 1974 (book III) and 1965 (Sources Chrétiennes 100, book IV).

${ }^{58}$ See Cyprian Testimonia ad Quirinum II,21.

${ }^{59}$ According to LXX. 
too, He suddenly removed those children belonging to the house of David, whose happy lot it was to have been born at that time, that $\mathrm{He}$ might send them on before into His kingdom; He, since He was Himself an infant, so arranging it that human infants should be martyrs, slain, according to the Scriptures, for the sake of Christ, who was born in Bethlehem of Judah, in the city of David (see Mt 2:16)"60.

He made a traditional exegesis of this passage in the way which was known already in Justin's times ${ }^{61}$. Christ is the one who destroy the magic cult, and for this reason He receives the "power of Damascus, and the spoils of Samaria". In this way Irenaeus try to say that it is the hidden power of Christ, who destroys the power of demons, meaning Amalek ${ }^{62}$, because until the incarnation day, the "Word was invisible" ${ }^{63}$.

Presumably he is referring to the hiddenness of God's providential hand in the Saviour, Baby Jesus. The second mention (the third being similar) links Exod 17:10-13 and Num 21:6-9. The Lord like Moses „by the spreading forth of hands, did destroy Amalek, and vivify man from wound of the serpent, by means of faith which was [exercised] towards Him" $^{\prime 64}$. Jesus Christ "destroyed and conquered the enemy of Man, and gave to His handiwork victory against the adversary"

Amalek would appear to be the snake of Gen 3:14-15, and Jesus crucified is prefigured by the lifting up of the snake in the desert and by Moses outstretched arms on the hill above the battle against Amalek. Irenaeus uses a common typology of the Moses' prayer and the symbol of the copper snake ${ }^{65}$.

Interestingly, the third mention is followed by a proof against Marcion $^{66}$, just as Origen spiritualizes Amalek in his proof against Celsus, who, like Marcion, was trying to drive a wedge between Jesus and the God of the Old Testament ${ }^{67}$.

60 Adversus Haereses IV, 24.

61 See Dial. cum Trypho 77-78 (Is 8:4) i 49,8 (Exod 17:16); see SC 210, p. 320.

62 About this interpretation as Amalek in St. Irenaeus see SC 210, p. 320.

63 See A. Orbe, Antropología de San Ireneo (Biblioteca de autores cristianos 286), Madrid 1969, p. 101.

64 Adversus Haereses IV, 24,1.

65 The brass serpent (Num 21:8-9) is a type of the Saviour (see Jn 3:14), whereas He himself is not e serpent; Origen, Homiliae in Ezechielem XI,3, see also In Joannem, fr. 39.

66 Ibidem 33,2.

67 Origen, Contra Celsum VII, 18. 
For the author of the Adversus Haereses the most important aspect is the Christology, because the prayer of Moses is the prefiguration of the sacrifice of Christ on the cross. The confirmation of this idea one can find in the Demonstratio praedicationis apostolicae: it was the our Saviour who "made to enter into the inheritance of the fathers; whom not Moses, but Jesus puts in possession of the heritage who also delivers us from Amalek by the expansion of His hands, and brings us to the kingdom of the Father"68.

One can find the typology developed by Justin and Irenaeus in the works of the Latin writers. For example, Tertullian noticed that the prayer of Moses who prayed with the open arms, was very significant.

"Why did Moses on that occasion only when Joshua was warring against Amalek (cum Iesus adversus Amalech proeliabatur), pray sitting and with outstretched hands, when in such critical circumstances he might have been expected rather to commend his prayer by bended knees, by hands beating the breast, and face turned down to the ground ${ }^{69}$ ? Evidently because on that occasion, when one was contending who bore our Lord's name, as our Lord himself was afterwards to contend against the devil, the form of the cross was essential ${ }^{70}$, so that by it Joshua might gain the victory (dimicaturi quandoque adversus diabolum, crucis quoque erat habitus necessarius, per quam Iesus victoriam esset relaturus)" ${ }^{\prime 71}$.

The similar way of exegesis of his "master" 72 fallows the bishop of Carthage - Cyprian (circa 258). In the second book of the testimony

${ }^{68}$ Demonstratio 46.

${ }^{69}$ See De oratione 17; 15-16. The faithfulness in prayer of Moses is sharply contrasted with the futility of contemporary Jewish prayer. The real successors to those who reached great heights of prayer in Old Testament times are not the Jews of Tertullian's day, but those, of every nation, who now invoke Christ (see Adversus Iudaeos 5). Pagan prayer is portrayed as widespread, but as external rather than sincere, external its manifestations as well as in the benefits it seeks. In sharp contrast to this, Christian prayer is earnest; it is rightly based, both as regards its destination and its entitlement (see Apologeticum 18).

70 "Moses... afterwards set up a brazen serpent on a pole in the attitude of one hanging, and commended it to be gazed upon for healing. Why was this, except that here too he was asserting the power of our Lord's Cross, by which [that old] serpent, the devil, was being reduced to bondage, while to everyone wounded by spiritual snake-bites who should look upon it and believe in it, was promised healing of the bites of sins, and salvation from thence forward"; Adversus Marcionem III,18. On the serpent of brass see also De idolatria 5 .

${ }^{71}$ Adversus Marcionem III,18. See also Adversus Iudaeos 10.

72 See Hieronymus, De viris illustribus 53. Quoted in: J. Quasten, Patrologia, tom I, Casale Monferrato 1983, p. 574. 
wrote to Quirinus he interpreted this passage as follows: "In Exodus, when Moses, for the overthrow of Amalek, who bore the type of the devil, raised up his open hands in the sign... of the cross, and could not conquer his adversary unless when he had stet fastly persevered in the sign with hands continually lifted up ${ }^{\prime 73}$. The biblical scene ${ }^{74}$ offers more particularities: Aaron and Hur took a stone and placed it under Moses' arms, and he stated there on. "This is the stone in Exodus upon which Moses sate on the top of a hill when Jesus the son of Nave fought against Amalek; and by the sacrament of the stone, and the steadfastness of his sitting, Amalek was overcome by Jesus, that is, the devil was overcome by Christ"75 - explained the bishop of Carthago.

Cyprian puts attention on the typology which indicates Christ - the Son of God. In other works of the bishop of Carthage, who was more an action man than a speculative theologian, he will not takes often into account so large topics. In his exegesis, he was not so original as Tertullian, and had no the cohesion that Origen had, in his interpretation of the Bible ${ }^{76}$.

In the $3^{\text {rd }}$ century various writers employed repeatedly the typological exegesis of the battle with Amalekites. Archelaus (circa 278), bishop of Carchar in Mesopotamia, drew a typological parallel between Moses and Christ. He wrote: "Moses ... stretched forth his hands and fought against Amalek; and... the Lord Jesus, when we were assailed and were perishing by the violence of that erring spirit who works now in the just, stretched forth His hands upon the cross, and gave us salvation"77.

\section{ORIGEN'S INTERPRETATION}

Moses' outstretched or upraised arms-traditionally implying his communion with God on behalf of Joshua and his soldiers-appears to have given Israel's army confidence to fight against her enemies. Yet patristic sources see more in this episode than simple manifest faith in the power of prayer. Origen interprets this theme in term of the Christian

${ }^{73}$ Ad Quirinum XI, 8.

${ }^{74}$ See also Ad Fortunatum 8 (Ex 17:11-14).

${ }^{75}$ Ad Quirinum II,16.

${ }^{76}$ See J. Quasten, Patrologia, vol. I, p. 602.

77 Disputatio cum Manes. 
ability to raise the hands in prayer through the power of Christ's cross. Homily XI deals with Exod 17-18. In the Homily XI the very first words are a citation of 2 Tim 3:12: "Everyone who wants to live a godly life in union with Christ Jesus will be persecuted"78.

These words shed a very different light upon the subject of the battle with the Amalekites. Above, in the rabbinic commentaries, the prevalent idea was that the enemy attacks because Israel has sinned. Origen, quoting the NT, says the enemy attacks Israel who has not sinned, almost as a consequence of not sinning. Further on, in XI,I, Origen states that the proper name Sin means "temptation" and Rephidim means "healthy judgment", but he does not explain how he derives this. As the Israelites move out from Sin which is a desert, perhaps Origen is thinking of Jesus' temptations in the desert.

It is, in any case, resistance in time of temptation that brings about this healing. Origen quotes Apoc 2:7, addressed to the Church of Ephesus which had been suffering patiently without giving up, saying that the one who is victorious will eat from the tree of life, whose leaves, according to Apoc 22:2, are for healing.

In homily XI,2, Origen brings together different kinds of thirst thirst for water and thirst for hearing God's word, which latter is that suffered by sinners. There is a resemblance to the Mekilta commentary which says that the Israelites were weak because they had not been studying Torah. The God's Law being water which gives strength; however, the resemblance is not clear enough in its details to suggest that the one commentary might be borrowing from the other.

In Homily XI, 3 begin the commentary on the battle with Amalek. Origin puts the battle in its context: it takes place after the people have eaten the bread from heaven (Exod 16:4) and drunk the water from the rock (Exod 17:6). Before this, the Lord fought for them (Exod 14:14), but now the people fight - and win. Origen's hearers must prepare themselves also for the battle, and this battle is against the "Strong Man" ${ }^{79}$. War being imminent, Moses tells Joshua to choose men to go out and fight against Amalek. Joshua in the LXX is Jesus - the first mention of the name Jesus in the Bible. Jesus is to choose men. Moses is the Law, so it is the Law which mysteriously invokes Christ, asking him to choose out

\footnotetext{
${ }^{78}$ Homiliae in Exodum XI, 1-4. See also Homiliae in Leviticum VI,6.

${ }^{79}$ According to $\mathrm{Mt}$ 12:29.
} 
powerful men from among the people ${ }^{80}$ : the prerogative lies with Jesus, who himself said: "You did not choose me, but I chose you" (J 15:16). Jesus it is who fights Amalek, the Strong Man ${ }^{81}$.

Origen certainly sees Jesus crucified in the image of Moses lifting his hands, while he also notes the difference - Jesus is not simply another Moses. Lifting up the hands is figurative: it means offering upward towards God, towards heaven, as opposed to doing base deeds at the low level of earth $^{82}$, and this brings victory over Amalek, where Amalek is a spiritual enemy, the spiritual enemy which Eph 6:12 says rules this dark world we live $i^{83}$. According to Origen, it is in the Christian that the Lord fights against Amalek, as if by a "secret hand": Understand from this ${ }^{84}$ very clearly who ought to be understood as Amalek, whom God is said to combat from generation to generation with a hidden, that is, an invisible ${ }^{85}$, hand".

Origen adds now that the victory is won not only by actions, but by prayers ("the Lord my Refuge") ${ }^{86}$. He says that this is a tradition handed on from the ancients (he does not say from whom), that God's people used to bring the enemy down not with weapons but with vocal prayers $^{87}$. Perseverance in prayer is the battle of the Christian, which triumphs over the enemy.

The prophecies of Balaam ${ }^{88}$ are commented on by Origen in homilies XV - XIX. Although in the Scripture the verses Num 24:7.20 appear to be the only references to Amalek (allowing that Num 24:7 really speaks of Agag the Amalekite king), the whole section should be taken into consideration to give a feel for the general context: Num 24:9b, for example says, "Whoever blesses Israel will be blessed, and whoever curses Israel will be cursed" $"$.

80 "Powerful" is not in the Hebrew, but is in the LXX.

${ }^{81}$ Mt 12:29.

82 Origen may be drawing on Philo from Alexandria.

${ }^{83}$ The passage in Eph 6 is a clear and powerful statement of the spiritual warfare of the Christian.

${ }^{84}$ See Exod 17:6.

${ }^{85}$ See Deut 25:17-18.

${ }^{86}$ According to LXX. The rabbis read this expression as "a hand on the throne of $\mathrm{YHWH}^{\prime \prime}$.

87 Suggested perhaps by Ps 8:1-2.

${ }^{88}$ Num 23:18-24:24. Josephus Flavius omits the passage in Balaam's prophecy predicting the destruction of Amalek (Num. 24:20).

${ }^{89}$ Notice the distinction between Amalekites and Kenites in Num 24:20-21 and 1 Sam 15:6. 
"We can hunt for an interpretation of this vision too that is not far from the truth... It seems necessary to me to search in the divine Scriptures to find out in which places or a what time the name of Amalek is written, and to find out from what race that nation descends. For what we are seeking here will be more easily understood if this is set forth from the many passages that have been written about the same subject" ${ }^{\prime \prime 90}$.

Origen's commentary on Num 24:17b in XVIII,4 regarding Moab and Seth, introduces a completely new aspect to the discussion of Israel's enemies in the time of the Messiah. Origen again spiritualizes the enemy, who becomes the devil, and he also sees represented the "war" between Israel and her enemies as the "war" between the soul and the body.

The new aspect is that in the time of the Messiah and the sending of the Spirit, the devil is conquered and also the soul regains rightful dominion over the body. In this way, Israel's human opponents are destined to become part of the Messiah's inheritance, just as also the body is to be resurrected and be part of the inheritance together with the soul. Of great importance to the discussion on Amalek is Origen's insistence that human beings are not the real enemy, and the Messiah (Origen uses the Greek, Chrystos) is able to set these human beings free from their subjugation to devilish powers. In this commentary, therefore, Origen's view of universal salvation in Christ appears to include human beings and to exclude devils.

Homily XIX, 1-2 is a long discussion of Num 24:20, in which Origen himself believes it necessary to bring in other passages from Scripture ${ }^{91}$ in order to discover who Amalek is. He recalls and cites the conflicting passages Gen 14:7 and Gen 36:12.16: two different Amaleks, he wonders, but he does not pursue this possibility further. The first, the conquest of the land (or princes) of the Amalekites at the time of Abraham, is completely spiritualized by Origen, making use of the meanings of the proper names "Kadesh" (Holiness) and En-Mishpat" (Spring of Judgment). "In that sanctity, which is Kadesh, there is a 'well of judgment'. For everyone who converts himself to sanctity always has before his eyes the well of judgment. For he looks forward to the day of judgment and contemplates with a purified heard both the penalties

${ }^{90}$ Homiliae in Numeros XIX,1.

${ }^{91}$ Origen says of Gen 14:7 that it is the first passage containing Amalek that he remembers. This author seems, therefore, to know Scripture very thoroughly, and to rely on his memory rather than upon the concordances and indexes used commonly today. 
for those who are evil and the blessings for those who are godly. And by doing this, a person wrecks and casts down all the rulers of the Amalekites. But if they do not convert themselves to Kadesh, that is, to sanctity and the well of judgment, they do not think about the future day of judgment ${ }^{\prime \prime 2}$. Those who are converted to a holy life and keep ever before them the last judgment, are the ones who defeat the Amalekites.

The name "Amalek" is not the "people who lick" as explained by the rabbis ${ }^{93}$, but means "he who seizes peoples" or "makes the people turn away" (i.e. from God to idolatry) and "eats them up". About Gen 36:12.16, Origen says that (according to the meanings of their names) the son of such parents must necessarily be an enemy of Israel, and quotes Exod 17:8-16 ${ }^{94}$ and Deut 25:17-18. Concerning the latter, he notes that Amalek was only able to get the tail-enders, those who in the Christian life do not strive to go on, forgetting what they have left behind. "Those who turn back to what are holy and who convert them-selves to sanctification kill and destroy Amalek, namely, him who devours or turns aside the people. But who else is there who turns aside the people from God if not the contrary power and the spiritual forces for wickedness? Well then, who are the rulers of these? Doubtless it is those principalities against whom the saints do combat. For them there are struggles against the principalities and powers and rulers of this world; yet the saint are unable to overcome them, unless they are converted to sanctity" ${ }^{\prime 95}$.

The Alexandrian quotes Deut 25:17-18 and explains: "[Amalek] was unable to cut off his [of Israel] head, but only his tail, that is, he was able to reach those who were behind, who followed last, but not those who «forgetting the things are stretch forth for the things that are ahead» (Phil 3:13) ${ }^{96}$. And I think this is why the Lord gave the command in the Gospel and said: "Once the hand is laid on the plough, no one who looks back is fit for the kingdom of God» (Lk 9:62). And he says

${ }^{92}$ Homiliae in Numeros XIX,1.

93 Pesikta de Rav Kahana 3,8 and Philo, De migratione 143; Leges allegoriarum III, 186-186. Philo says that Amalek not only licks up, but eats up the soul before licking it out. Possibly Origen has this in mind here, but why does he omit the licking out?

${ }^{94}$ In Exod 17: 14-16 the Vulgate has "Dominus exaltatio mea" and "manus soli Domini" respectively.

${ }_{95}$ Homiliae in Numeros XIX,1.

96 „I do not reckon myself as having taken hold of it; I can only say that forgetting all that lies behind me, and straining forward to what lies in front". 
this justly; for if someone should be found behind in the tail, Amalek will cut him off"'97.

In the homiletic cycle on Numbers Origen indicates that it is an example $^{98}$ of the necessity to be zealous and vigilant in the Christian life, and illustrates the ruinous folly of sparing Amalek, the invisible forces that are capable of causing the Christian to turn away from his goal (the Promised Land, the kingdom, heaven). This danger is further illustrated by 2 Sam 1:1 ff., where David does not obtain his kingship until he has defeated Amalek - Amalek, who in the meantime had done much damage (Origen says, in fact, that the spiritual Amalekites had succeeded in taking prisoner all men, Jews and Gentiles, before the Advent of the Messiah). David, therefore, and so the Messiah, is the one who destroys the Amalekites and returns to become King ${ }^{99}$.

Finally Origen returns to Num 24:20! According to him the words " "Amalek is the beginning of nations» (Num 24:20) can in no way be applied to that who was in the flesh at that time. For he was not first in terms of the antiquity of his origin. Rather, this is better to refer this to the invisible Amalek, who is called Amalek by virtue of his turning aside people from God and making pagans out of the worshipers of God. And therefore he is rightly called «the beginning of nations», as it were, as a kind of hostile power that first gave the beginning to men becoming pagans «that they exchanged the glory of the immortal God for an imitation, for the image of a mortal human being, or of birds, or animals, or crawling things» (Rom 1:23) and «they exchanged God's truth for a lie and have worshipped and served the creature instead of the Creator» (Rom 1:25). For just as Christ has been recorded as the beginning of the people of God, so, on the contrary, Amalek is the beginning of the people who turn away from God and who became pagan"100.

Amalek cannot be understood in human terms, since patently he was not the first of the peoples to arise. On the other hand, Amalek is the invisible foe, who steals the peoples and makes them into pagans

97 Homiliae in Numeros XIX,1.

${ }_{98}$ The theme refers to 1 Sam 15:1-11. Origen quotes these verses also in Homiliae in I Regum 5; 9.

${ }_{99}$ There may be a case for comparing Origen with Sanhedrin 4,5 and especially Sifre Deut Pisqa 67 where a tradition assigns to R. Judah a discussion of precedence between becoming King and destroying Amalek.

100 Homiliae in Numeros XIX,1. 
(idolaters). "[The Scripture] declares not only that the nation of Amalek will perish ${ }^{101}$, but his seed too. Now, when the nation is referred to the spiritual forces do wickedness, his seed is his perverse doctrine" ${ }^{\prime 102}$. It is this doctrine which is destined to perish ${ }^{103}$, not those who have been led astray by it, for these, when they are converted, will be saved. In this way, so concludes Homily XIX, 2, Origen refutes those who say the God of the Old Testament ${ }^{104}$ is hard and cruel because he commands the destruction of Amalek and his descendants. Amalek means the evil spirits, his descendants are the doctrines and superstitions which have led people astray into idolatry ${ }^{105}$.

Origen at one point wonders if there might not be two Amaleks, but he does not dwell on it very long. "Such persons are subjected to the rulers of Amalek; for the devours and consumes this people and he turns such a people from God" ${ }^{106}$. But also "they will afflict the Assyrians, namely, the race of demons"107. In the end of Homily XIX Origen announced: "Everything is said with edification in view and everything leads to the glory of God"108.

\section{DEVELOPMENTS OF EARLY CHRISTIAN TRADITION OF THE TYPOLOGY OF AMALEK}

In the case of Syrian authors it must be remembered that their lived in another chronological and cultural context. These writers had an

101 While there are several partial parallels among other peoples of antiquity for the divine command of mass extermination, they differ in that they are generally instances of a complete destruction of a given city or nation at a given time, whereas the destruction of the Amalekites is of a people and their descendants for all time. Josephus, Philo and the Church's Fathers were troubled by this command. See e.g. A. Sagi, The Punishment of Amalek in Jewish Tradition: Coping with the Moral Problem, Harvard Theological Review 87 (1994), p. 328, note 17. This author cites the Mishnah (Sanhedrin 4,6).

${ }^{102}$ Homiliae in Numeros XIX,1.

103 The Talmud's view is that the eradication of the Amalekites will not occur until the end of time.

104 This was a frequent charge against the God of the Old Testament made by Marcion and his followers.

105 See Origen's discussion on this in Contra Celsum VII, 18.

${ }^{106}$ Homiliae in Numeros XIX,2.

107 Homiliae in Numeros XIX,4.

108 Homiliae in Numeros XIX,4. 
unique experience of an ancient tradition of the Church, who took the inspiration from the Bible and from the Semitic way of understanding. This part of Christianity, where the most important writers were Afrahat and Ephrem, was not influenced by the Greek culture and her ideas. This is why their exegesis was often very close to the Jewish tradition of Talmud and Midrash. One can also find in their works the elements of the anti-Semitic polemics in the Syrian Church. However, it seems that until the beginning of IV a.C. the anti-Judaism inclination was very limited. On the other hand the interpretation of the Bible of both parts were very similar. All in all, a part from the geographical location, the whole ancient Church in his different parts was developing his own ideas in different directions and definitely the common theology was more important than the geography itself ${ }^{109}$.

Confirms this opinion Afrahat (IV century) surnamed the "Persian Sage", who fallows the Judaic tradition and he claims that an evil man of the name Hamman is the „survivor of Amalekites"110. The „Persian Sage" makes analysis of the battle between Israelites and Amalekites. Afrahat writes that: "Joshua armed himself and went out to fight with Amalekites and then Amalek was destroyed. [It happened] because of the cross, [meaning] thanks to open arms of Moses"111. His biblical story shows the faith of Moses: "By faith he spread out his hands and conquered Amalek, as is written: "His hands continued in faith till the setting of the Sun» (Exod 17:12)"112. Author also emphasized the fact that from all the sons of Esau only Amalek wanted to fight with the sons of Jacob, "so that his name was canceled"113. In one passage of Demonstrations one can see, that Afrahat using the Judaic tradition emphasized the mercy of God: "At that time they repented [of their actions] and they will return to Him"114. Aphrahat employed the typological exegesis for Exod 17 and

109 Por. S.D. Benin, Commandments, Covenants and the Jews in Aphrahat, Ephrem and Jacob of Sarug, D.R. Blumenthal (ed.), Approaches to Judaism in medieval times (Brown Judaic Studies 54), vol. 1, Chico-Kalifornia 1984, p. 149.

${ }^{110}$ See Demonstratio XIV,11. Agapius transmits a similar tradition; see Patrologia Orientalis 11, p. 79-80.

111 Demonstratio III,12. See also Commentary to Diatesseron 21,14; SC 121, p. 381. *

112 Transl. according to Peshitto; Demonstratio I,14.

113 Demonstratio III,13.

${ }^{114}$ Demonstratio III, 11. In order to give greater force to the subject, Aphrahat recalls the examples of the Old Testament, in which the Gentiles are represented as penitents and converts. 
paralleled Moses to Christ: "Moses conquered Amalek by the spreading out of his hands; and Jesus conquered Satan by the sign of His cross"115.

The next famous author provided [comes] from the region of Syria was Ephrem. He was not a speculative mind, but rather a poet who used to use in his works above all the imaginations and symbols. He believed that it is the best way to explain the Bible and the religions issues. $\mathrm{He}$ expressed himself severely about the Jews who rejected the Saviour. He goes further to demonstrate the lesson which the Nation failed to learn from the war against Amalek. But in the new salvation's economy the Nations believed in the hand of the Son which were stretched out and gained victory over their spiritual enemies ${ }^{116}$. In this manner, the fate of Amalek becomes the fake of Jews. Ephrem in particularly way makes an effort to present the passages in the Bible which in positive way he presents the gentile. For him the Amalekites was a paradigm of the Israelites who decided to be rejected and condemned. On the contrary, now the gentiles became the chosen people, meaning the majority of Christians in Ephrem's times.

In his Commentary on Exodus Ephrem writes: "The Amalekites came to fight with them, and Joshua went out to counter them while Moses went up to the mountain with the staff of God in his hand. Moses wasn't holding that staff except at the time of the miracles, so that you might know that it was the mystery of the cross which by it and its power he was performing all the miracles. Aaron and Hur... went up with Moses. By Moses' holding up of his hands Israel was prevailing and striking on the bold of the Nations who had threatens and come to fight the Nations. And at lowering of his hands the Nations were prevailing to strike on those who were always complaining against the Lord and Moses. By holding up his hand and the staff which was on his chest Moses shows clearly the sign of the cross in himself"117.

One of the Syrian writers Narsai attributes the victory to the miraculous Moses' staff. „Moses as a servant, carried the mystery of crucifixion" ${ }^{\prime \prime 18}$.

John Chrysostom wrote the following regarding the symbolic message of this Exodus passage: "See how the type was "given by

\footnotetext{
115 Demonstratio XXI,14.

116 See In Diatesseron 21,14.

117 In Exodum homilia XVII,8.

${ }^{118}$ Homilia 30.
} 
Moses», but the «truth came by Jesus Christ» (J 1:17). Again, when the Amalekites warred in Mount Sinai, the hands of Moses were supported, being stayed up by Aaron and Hur standing on either side of him (Exod 17:12); but when Christ came, He of Himself stretched forth His Hands upon the Cross. Hast thou observed how the type «was given» but «the Truth came»?"119.

One of the Cappadocian Fathers - Gregory of Nazianzus noted, "Moses is to conquer him by stretching out his hands upon the mount, in order that the cross, thus typified and prefigured, may prevail"120.

Indeed, most of the fathers tended to read the Hebrew Bible through Christian lenses, seeing references to, types and shadows of, and symbols for Christ in literally thousands of verses and stories scattered throughout the entirety of the Old Testament. Indicative of how the Fathers read the Biblical histories is the following comment from John of Damascus: "Likewise also did Moses' rod, when it smote the sea in the figure of the cross and saved Israel, while it overwhelmed Pharaoh in the depths; likewise also the hands stretched out crosswise and routing Amalek; and the bitter water made sweet by a tree, and the rock rent and pouring forth streams of water and the rod that meant for Aaron the dignity of the high priesthood: and the serpent lifted in triumph on a tree as though it were dead, the tree bringing salvation to those who in faith saw their enemy dead, just as Christ was nailed to the tree in the flesh of sin which yet knew no sin. The mighty Moses cried: "You will see your life hanging on the tree before your eyes», and Isaiah likewise, «I have spread out my hands all the day unto a faithless and rebellious people». But may we who worship this obtain a part in Christ the crucified"121.

Following the example of John of Damascus, we can see that for early Christians the message was mainly Christocentric. The faith in Jesus Christ made possible to successfully conquer all of our enemies and overcome all of our trials.

\section{CONCLUSION}

The most striking similarity between the Rabbis and the Fathers of the Church is their quite phenomenal knowledge of the Scriptures

119 In Johannem homilia XIV,4.

${ }^{120}$ Oratio 2 (In Defense of His Fight to Pontus).

${ }^{121}$ De fide orthodoxa IV, 21. 
and their use of texts from different books of the Bible to explain their meaning. Amalek is "the enemy" and Israel will always be fighting against him. One can find nothing in all rabbinic literature of an attempt to abrogate the divine commandment to eradicate the Amalekites and to leave open the road to repentance. Josephus' account of the attack of the Amalekites upon the Israelites is so much more extensive than the accounts in the Pentateuch. Philo of Alexandria has totally omitted the divine injunction to eradicate the Amalekites as a people and instead has equated them with passion or evil. Amalek may not appear in the New Testament as a proper name, but the possible reading on Christian Literature alongside the rabbinic texts is suggestive. A common feature of Christian authors to interpret the events of the Old Testament in the light of the New. For this reason, the victory of Christ over evil and on his opponents is strongly emphasized. The re-reading of the biblical story according to this perspective, despite the lack of direct correspondences, allows finding that Amalek is present as the spiritual reality.

In Origen this approach is much more clearly defined in his explicitly spiritualizing reading. This Alexandrian author does bring in a new idea that of the attacks from Amalek coming as a result of holy - living and not as a result of sin. The coming of the Saviour meant the reconciliation of the whole humanity - Jacob and Esau. The enemy is no longer men, because all have become brothers, but the "prince of this world" and the "father of lies" - Satan.

The hope is that even this small - scale research is sufficient to shed light upon the problem of Amalek and the Amalekites in the ancient Christian traditions.

Streszczenie. Amalek i Amalekici w starożytnej literaturze chrześcijańskiej. Zarówno w tradycji judaistycznej, jak i u autorów chrześcijańskich Biblia stanowiła podstawę rozważań o Amaleku i Amalekitach. Ta wspólna baza, o której stanowił objawiony teksty sprawia, że w tak różnych od siebie tradycjach pojawiają się podobne elementy, chociaż nie brak różnic merytorycznych. Stanowi o nich nie tylko typologia chrystologiczna rozwinięta przez autorów wczesnego Kościoła, lecz perspektywa otwarta przez Orygenesa, który potraktował kwestię Amaleka metodycznie i z naukową starannością analizy szkół retorycznych swojej epoki. U doktora aleksandryjskiego na czoło wysuwa się interpretacja alegoryczna. według niej Amalek to co prawda wróg duchowy, lecz atakujący nie tylko z powodu grzechu, konieczność walki z nim dotyka bowiem chrześcijan prowadzących uświęcone życie. Nieprzyjacielem nie jest już człowiek, wszyscy bowiem stali się braćmi, lecz „władca tego świata” i „ojciec kłamstwa” - szatan. Cechą wspólną 
większości autorów chrześcijańskich jest interpretacja wydarzeń Starego Testamentu w świetle Nowego, stąd tak mocne akcentowanie zwycięstwa Chrystusa nad złem i przeciwnikami. Odczytywanie w takiej perspektywie historii biblijnej, nawet mimo braku bezpośrednich powiązań, pozwala odkryć, że "Amalek” był obecny jako rzeczywistość duchowa.

Słowa kluczowe: Amalek/Amalekici, Biblia, egzegeza patrystyczna, typologia.

Abstract. Amalek and the Amalekites in the ancient Christian literature. This research shed light upon the problem of Amalek and the Amalekites in the Patristic tradition. The Christian lecture shows the biblical background but also the rabbinic literature treated systematically this figure. Amalek is "the enemy" and Israel will always be fighting against him. Josephus' account of the attack of the Amalekites upon the Israelites is so much more extensive than the accounts in the Pentateuch. Philo of Alexandria has totally omitted the divine injunction to eradicate the Amalekites. The role of the Messiah - Christ is still obscure in the rabbis. Amalek may not appear in the New Testament as a proper name, but the possible reading on Christian Literature alongside the rabbinic texts is suggestive. Origen of Alexandria does bring in a new idea, that of the attacks from Amalek coming as a result of holy - living and not as a result of sin. The Post-Nicene traditions developed the specific typology of Amalek.

Keywords: Amalek/Amalekites, Bible, Patristic interpretation, typology. 